\title{
Efficient Asymmetric Synthesis of the Vasopeptidase Inhibitor BMS-189921
}

\author{
Janak Singh,* David R. Kronenthal, Mark Schwinden, Jollie D. Godfrey, \\ Rita Fox, Edward J. Vawter, Bo Zhang, Thomas P. Kissick, Bharat Patel, \\ Omar Mneimne, Michael Humora, Chris G. Papaioannou, Walter Szymanski, \\ Michael K. Y. Wong, Chien K. Chen, James E. Heikes, John D. DiMarco, \\ Jun Qiu, Rajendra P. Deshpande, Jack Z. Gougoutas and Richard H. Mueller
}

\section{Supporting Information}

Experimental: ${ }^{1} \mathrm{H}$ NMR spectra were recorded on a JOEL FX $270 \mathrm{MHz}$ spoectrometer using TMS as internal standard and ${ }^{13} \mathrm{C}$ NMR were recorded at 68 MHz. Optical rotations were recorded at ambient temperature. HPLC analysis results are described as area percent (AP).

$\mathbf{N}$-(Benzyloxycarbonyl)- $\alpha$-phosphono-glycine trimethyl ester $\mathbf{2}$ and (S)-2(acetylthio)benzenepropanoic acid $\mathbf{1 6}$ are commercially available from Aldrich Chemical Company and Davos Chemical corporation respectively.

Part I: $\quad$ Synthesis of (S)- $\alpha$-aminoazepinone $\mathbf{6 b}$ via enantioselective reduction of enamide 3.

2,6-Dinitro-2, 6-dimethyl-3-heptanol (1).

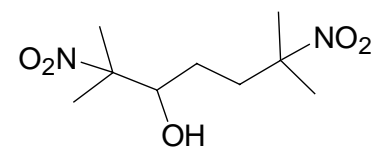

Acrolein $(71.6 \mathrm{~mL}, 1.07 \mathrm{~mol})$ was added to a mixture of 2-nitropropane $(480 \mathrm{~mL}$, $5.36 \mathrm{~mol})$ and $\mathrm{Et}_{3} \mathrm{~N}(14.9 \mathrm{~mL}, 0.11 \mathrm{~mol})$ under an argon atmosphere. (Caution for scaleup: The reaction is strongly exothermic and it is advisable to add acrolein slowly and use an ice bath to keep the temperature around $20^{\circ} \mathrm{C}$ ). After $20 \mathrm{~h}$ the 
mixture was washed with $1 \mathrm{~N} \mathrm{HCl}(600 \mathrm{~mL})$. The light blue organic phase was washed further with aqueous $\mathrm{NaHCO}_{3}(350 \mathrm{~mL})$, brine $(200 \mathrm{~mL})$, dried over $\mathrm{Na}_{2} \mathrm{SO}_{4}$, filtered and concentrated under vacuum at $35^{\circ} \mathrm{C}$. The oil was dissolved in heptane $(200 \mathrm{~mL})$ and evaporated. This process was repeated and the light blue solid was dissolved in toluene $(500 \mathrm{~mL})$ at $60^{\circ} \mathrm{C}$ and allowed to cool slowly to 20 ${ }^{\circ} \mathrm{C}$. After standing overnight, the product was filtered, washed with hexane/toluene $(1: 2,40 \mathrm{~mL})$ and dried under vacuum to yield $96.8 \mathrm{~g}$ of product $\mathbf{1}$ as a white solid HPLC AP 99.5. The mother liquor was diluted with hexane (200 $\mathrm{mL}$ ) and cooled to $0{ }^{\circ} \mathrm{C}$. After 30 minutes the solid was isolated as above to give $72.6 \mathrm{~g}$ (AP 98.3) of 1, combined yield $=68 \%$. ${ }^{1} \mathrm{H} \mathrm{NMR}\left(270 \mathrm{MHz}, \mathrm{CDCl}_{3}\right) \delta, 1.3$ - 1.7 (m, $2 \mathrm{H}), 1.69$ (s, $3 \mathrm{H}), 1.7$ (s, $3 \mathrm{H}), 1.74$ (s, $3 \mathrm{H}), 1.76$ (s, $3 \mathrm{H}), 2.0$-2.2 (m, $1 \mathrm{H}), 2.38-2.40(\mathrm{~m}, 1 \mathrm{H}), 2.48-2.6(\mathrm{~m}, 1 \mathrm{H}) .{ }^{13} \mathrm{C} \mathrm{NMR}\left(68 \mathrm{MHz}, \mathrm{CDCl}_{3}\right)$ $\delta, 20.3,23.8,25.8,26.1,26.8,75.5,86.8,91.1$. IR (KBr) 3530, 1539, $1530 \mathrm{~cm}^{-1}$; Anal. Calcd for $\mathrm{C}_{9} \mathrm{H}_{18} \mathrm{~N}_{2} \mathrm{O}_{5}$ : C, 46.15; H, 7.74; N, 11.96; Found: C, 46.13; H, $7.83 ; \mathrm{N}, 12.03$. $^{2}$

(z)-6-Methyl-6-nitro-2-[[(phenylmethoxy)carbonyl]amino]-2-heptanoic acid, methyl ester (3).

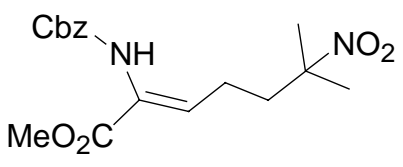

1,8-Diazabicyclo[5.4.0] undec-7-ene $(69.5 \mathrm{~mL}, 0.455$ mole) was added dropwise to a solution of (d,1)-Cbz- $\alpha$-phosphonoglycine trimethylester $(54.8 \mathrm{~g}, 165 \mathrm{mmol})$ in $\mathrm{CH}_{2} \mathrm{Cl}_{2}(270 \mathrm{~mL})$. precooled to $-20^{\circ} \mathrm{C}$ under a nitrogen atmosphere. ${ }^{3}$ The mixture

\footnotetext{
${ }^{1}$ HPLC method: Column: YMC S3 ODS 6.0 x 150.0; Solvent A: $100 \% 0.2 \%$ aqueous $\mathrm{H}_{3} \mathrm{PO}_{4}$. Solvent B: $90 \% \mathrm{CH}_{3} \mathrm{CN}$ in water. Gradient: $10 \%$ to $100 \% \mathrm{~B}$ in $30 \mathrm{~min}$; flow rate $1.5 \mathrm{ml} / \mathrm{min}$; wave length $205 \mathrm{~nm}$. $\mathrm{R}_{\mathrm{t}}$ of $121.4 \mathrm{~min}$.

${ }^{2}$ Rosini, G.; Marotta, E.; Ballini, R.; Petrini, M. Synthesis, 1986, 237.

3 (a). Schmidt, U.; Lieberknecht, A.; Wild, J. Synthesis, 1984, 53. (b). Kazmaier, U. Tetrahedron Lett., 1996, 37, 5351. (c). Cis geometry of olefin 3 was confirmed by single crystal $x$-ray analysis. Coordiantes
} 
was stirred for 5 minutes and a solution of carbinol $1(38.7 \mathrm{~g}, 165 \mathrm{~m}$ mole $)$ in $\mathrm{CH}_{2} \mathrm{Cl}_{2}(150 \mathrm{~mL})$ was added slowly via a cannula. Additional $\mathrm{CH}_{2} \mathrm{Cl}_{2}(100 \mathrm{~mL})$ was used to transfer the residual material. The temperature was maintained at -20 ${ }^{\circ} \mathrm{C}$ during the addition. The mixture was allowed to warm to $0{ }^{\circ} \mathrm{C}$ and stirred for 5 h below $5{ }^{\circ} \mathrm{C}$ and at $20^{\circ} \mathrm{C}$ for $1 \mathrm{~h}$. The reaction was complete by HPLC analysis. ${ }^{4}$ The solution was concentrated under vacuum at $35{ }^{\circ} \mathrm{C}$ and the resulting oil was dissolved in EtOAc $(500 \mathrm{~mL})$ and washed consecutively with $1 \mathrm{~N} \mathrm{HCl}(400 \mathrm{~mL})$, saturated aqueous $\mathrm{NaHCO}_{3}(200 \mathrm{~mL}), 10 \% \mathrm{NaHSO}_{4}(200 \mathrm{~mL})$ and brine $(200$ $\mathrm{mL})$. The solution was dried $\left(\mathrm{MgSO}_{4}\right)$, and stirred with charcoal (2 $\mathrm{g}$ activated carbon) for $0.5 \mathrm{~h}$. The mixture was filtered through a silica gel pad (60 g) and the product eluted with EtOAc (1 l). The solvent was evaporated to give $62.7 \mathrm{~g}$ (yield $\sim 99 \%$ ) of olefin 3 (AP 89; contains 7\% E-isomer). ${ }^{1} \mathrm{H} \mathrm{NMR}\left(500 \mathrm{MHz}, \mathrm{CDCl}_{3}\right) \delta$, $1.56(\mathrm{~s}, 6 \mathrm{H}), 2.05-2.09$ (m, $2 \mathrm{H}), 2.15-2.2(\mathrm{~m}, 2 \mathrm{H}), 3.8(\mathrm{~s}, 3 \mathrm{H}), 5.1(\mathrm{~s}, 2 \mathrm{H})$, $6.3(\mathrm{bs}, 1 \mathrm{H}), 6.5(\mathrm{t}, 1 \mathrm{H}, \mathrm{J}=7.4), 7.3-7.4(\mathrm{~m}, 5 \mathrm{H})$. olefinic proton in the minor trans isomer at $6.8 \mathrm{ppm}(\mathrm{t}, 1 \mathrm{H}, \mathrm{J}=7.5 \mathrm{~Hz}) .{ }^{13} \mathrm{C} \mathrm{NMR}\left(68 \mathrm{MHz}, \mathrm{CDCl}_{3}\right) \delta, 24.2$, $26.2,39.2,53.0,68.0,88.2,126.3,128.6,128.8,128.9,129.1,135.3,136.4,154.4$, 165.2. IR ((KBr) 3325, 1719, $1661 \mathrm{~cm}^{-1}$. MS (ESI) $\mathrm{M}-\mathrm{H}=349$. Anal. calcd for $\mathrm{C}_{17} \mathrm{H}_{22} \mathrm{~N}_{2} \mathrm{O}_{6}:$ C, 58.28; H, 6.33; N, 8.0; Found: C, 58.17; H, 6.55; N, 8.14. ${ }^{3 \mathrm{c}}$

\footnotetext{
from the X-ray determinations have been deposited in the Cambridge Crystallographic Database and can be obtained upon request to the Director, Cambridge Crystallographic Data Center, 12 Union Road, Cambridge, CB2 1EZ, UK.

${ }^{4}$ HPLC method same as in footnote 1: $\mathrm{R}_{\mathrm{t}}$ phosphonate 2, $15.6 \mathrm{~min} ; \mathbf{1}, 18.7 \mathrm{~min} ; \mathrm{Z}$ and E-alkenes, 23.3 and 24.5 min.
} 
(S)-6-Methyl-6-nitro-2-[[(phenylmethoxy)carbonyl]amino]heptanoic-acid, methyl ester (4a).

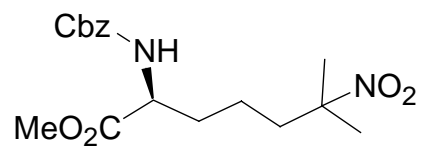

A solution of enamidoester 3 (274 g, 0.761 mole) in MeOH (1330 mL, presparged with argon gas) in an Ace Glass pressure vessel was sparged with argon gas for $0.5 \mathrm{~h}$ while stirring. Chiral catalyst (+)-1,2-bis((2S,5S)-2,5-diethylphospholano)benzene(cyclooctadiene)rhodium(I)trifluoromethane-sulfonate $(0.245 \mathrm{~g}, 0.339 \mathrm{x}$ $10^{-3}$ mole $)^{5}$ was added and the vessel was evacuated and pressurized to 40 psi three times with $\mathrm{H}_{2}$. The reactor was then pressurized with $\mathrm{H}_{2}$ to 40 psi and stirring was continued at ambient temperature for $17 \mathrm{~h}$. The reaction was monitored by ${ }^{1} \mathrm{H}$ NMR, which indicated more than $50 \%$ remaining starting material 3. A second batch $(0.274 \mathrm{~g})$ of the catalyst was added and the hydrogenation was continued for an additional $24 \mathrm{~h} .{ }^{1} \mathrm{H}$ NMR indicated that the reaction was complete. The solvent was evaporated to give $254.8 \mathrm{~g}$ of dark oil. The oil was dissolved in EtOAc - n-hexane $(1: 1,500 \mathrm{~mL})$ and passed through a pad of silica gel $(12.5 \times 15 \mathrm{~cm})$. The product was eluted with of EtOAc - nhexane $(1: 1,2.71)$. Fractions containing product were evaporated to furnish $263 \mathrm{~g}$ (quantitative yield) of the ester 4a. HPLC ee $=99.4 \% .{ }^{1} \mathrm{H}$ NMR $(270 \mathrm{MHz}$, $\left.\mathrm{CDCl}_{3}\right) \delta, 1.3-1.5(\mathrm{~m}, 1 \mathrm{H}), 1.68(\mathrm{~s}, 3 \mathrm{H}), 1.70(\mathrm{~s}, 3 \mathrm{H}), 1.70-1.8(\mathrm{~m}, 2 \mathrm{H}), 1.9-$ $2.1(\mathrm{~m}, 3 \mathrm{H}), 3.9(\mathrm{~s}, 3 \mathrm{H}), 4.48-4.58(\mathrm{~m}, 1 \mathrm{H}), 5.3(\mathrm{~s}, 2 \mathrm{H}), 5.5$ - $5.6($ broad d, 1

\footnotetext{
${ }^{5}$ Burk, M. J.; Feaster, J. E.; Nugent, W. A.; Harlow, R. L. J. Am. Chem. Soc., 1993, 115, 101125.

${ }^{6}$ (a). HPLC method same as in footnote 1: $\mathrm{R}_{\mathrm{t}}$ product $4 \mathrm{a} 24.1 \mathrm{~min}$. (b). Chiral HPLC was conducted on Chiralcel OD-R $4.6 \times 250 \mathrm{~mm}, 10 \mu \mathrm{m}$, mobil phase $3: 2 \mathrm{H}_{2} \mathrm{O}: \mathrm{CH}_{3} \mathrm{CN}$, column temperature $35^{\circ} \mathrm{C}$, flow rate $0.5 \mathrm{ml} / \mathrm{min}$., UV wave length $210 \mathrm{~nm}$. A reference sample of the R-enantiomer (i) was prepared by the reduction of enamidoester (3) with catalyst of opposite chirality $\left[\mathrm{H}_{2}\right.$, ((COD) Rh-(R,R) Et-DuPHOS)OTf, $\mathrm{MeOH}, 40 \mathrm{psi}]$ in $98 \%$ yield, ee $99.7 \%$.
}

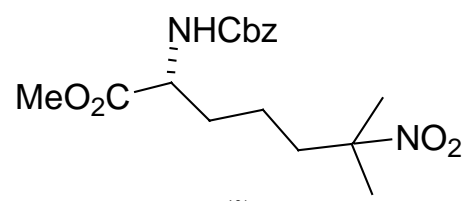

(i) 
$\mathrm{H}), 7.5(\mathrm{~s}, 5 \mathrm{H}) .{ }^{13} \mathrm{C}$ NMR $\left(68 \mathrm{MHz}, \mathrm{CDCl}_{3}\right) \delta, 17.5$ 19.9, 25.3, 26.0, 32.4, 40.0, 52.3, 53.3, 60.3, 66.9, 87.8, 128.0, 128.1, 128.4, 136.1, 155.8, 172.6. MS (ESI) M $+\mathrm{H}_{2} \mathrm{O}=370 . \quad[\alpha]_{\mathrm{D}}=-7.6(\mathrm{c}=1,95 \% \mathrm{EtOH})$. Anal. calcd for $\mathrm{C}_{17} \mathrm{H}_{24} \mathrm{~N}_{2} \mathrm{O}_{6} \cdot 0.065$ $\mathrm{H}_{2} \mathrm{O}$ : C, 57.75; H, 6.88; N, 7.93, $\mathrm{H}_{2} \mathrm{O}, 0.33$; Found: C, 57.42; H, 6.93; N, 7.83, $\mathrm{H}_{2} \mathrm{O}, 0.33$.

(S)-6-Methyl-6-amino-2-[[(phenylmethoxy)carbonyl]amino]heptanoicacid, methylester $(\mathbf{4 b})$.

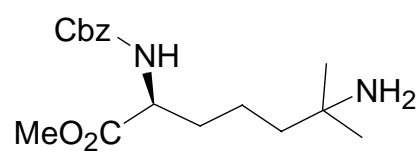

Acetyl chloride $(110 \mathrm{~mL}, 1.55 \mathrm{~mol})$ was added dropwise over $0.5 \mathrm{~h}$ to a solution of nitroester $4 \mathbf{a}(54.6 \mathrm{~g}, 155$ moles $)$ in $\mathrm{MeOH}(800 \mathrm{~mL})$ pre-cooled to $0{ }^{\circ} \mathrm{C}$ under an argon atmosphere. The internal temperature of the reaction mixture was maintained between 0 to $12{ }^{\circ} \mathrm{C}$. Zn dust $(132 \mathrm{~g}, 2.02$ mole $)$ was added portionwise while keeping the temperature at 0 to $12^{\circ} \mathrm{C} .^{7}$ After the addition was complete the mixture was warmed to $55^{\circ} \mathrm{C}$ and stirring was continued for $2 \mathrm{~h}$. HPLC ${ }^{8}$ showed complete absence of the starting material 4a. The mixture was cooled to ambient temperature, filtered and solvent was evaporated under vacuum at $35{ }^{\circ} \mathrm{C}$. The resulting white slurry was dissolved in $\mathrm{H}_{2} \mathrm{O}(500 \mathrm{~mL})$ and the $\mathrm{pH}$ of the solution was adjusted to 1.1 with conc. $\mathrm{HCl}(20 \mathrm{~mL})$. The cloudy solution was washed with EtOAc ( $3 \times 350 \mathrm{~mL})$. The aqueous layer containing the $\mathrm{HCl}$ salt of $\mathbf{4 b}$ was concentrated under vacuum and the semi-solid was redissolved in water ( $500 \mathrm{~mL})$ and washed with MTBE $(2 \times 200 \mathrm{~mL})$. The aqueous layer was cooled to $0{ }^{\circ} \mathrm{C}$ and basified with cold conc. aq $\mathrm{NH}_{4} \mathrm{OH}(120 \mathrm{~mL})$ to raise the $\mathrm{pH}$ to 10.7 . The milky

\footnotetext{
${ }^{7}$ (a). Bryce, M. R.; Gardiner, J. M.; Hursthouse, M. B.; Short, R. L. Tetrahedron Lett. 1987, 34, 577. (b). Adams, J. P.; Box, D. S. J. Chem. Soc., Perkin Trans. I, 1999, 749.

${ }^{8} \mathrm{HPLC}$ method same as in footnote $1: \mathrm{R}_{\mathrm{t}}$ product $12.5 \mathrm{~min}$.
} 
solution was extracted with $\mathrm{CH}_{2} \mathrm{Cl}_{2}(3 \times 250 \mathrm{~mL})$. The organic extract was dried by stirring over $\mathrm{MgSO}_{4}$, filtered and evaporated in vacuum to give $46.1 \mathrm{~g}$ (yield $85 \%)$ of the aminoester $\mathbf{4 b}$ as a light yellow liquid. ${ }^{1} \mathrm{H}$ NMR $\left(270 \mathrm{MHz}, \mathrm{CDCl}_{3}\right) \delta$, 1.2 (s, $6 \mathrm{H}), 1.5$ (br s, $4 \mathrm{H}), 1.7-1.8$ (m, $1 \mathrm{H}), 1.9$ (m, $1 \mathrm{H}), 2.1$ (br s, $2 \mathrm{H}), 3.9$ (s, $3 \mathrm{H}), 4.5-4.6(\mathrm{~m}, 1 \mathrm{H}), 5.2(\mathrm{~s}, 2 \mathrm{H}), 5.5-5.6(\mathrm{~m}, 1 \mathrm{H}), 7.5(\mathrm{~s}, 1 \mathrm{H}) .{ }^{13} \mathrm{C}$ NMR $(68$ $\left.\mathrm{MHz}, \mathrm{CDCl}_{3}\right) \delta, 20.2,30.0,33.2,44.0,49.7,52.3,53.8,67.0,128.1,128.2$, 136.2, 155.9, 173.0. MS (ESI) $\mathrm{M}+\mathrm{H}=321, \mathrm{M}-\mathrm{H}=319$.

$N^{6}$-[2-(1,1-Dimethylethoxy)-2-oxoethyl]-6,6-dimethyl- $N^{2}-[($ phenylmethoxy)-carbonyl]-L-lysine, methyl ester (5a).

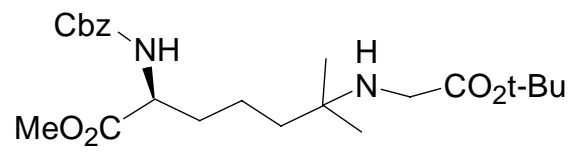

Diisopropylethyl amine (68.8 $\mathrm{mL}, 395$ mmoles) was added to a solution of aminoester $4 \mathbf{b}$ (42.5 g, 132 mmoles) in $\mathrm{CH}_{3} \mathrm{CN}(650 \mathrm{~mL})$ at $20{ }^{\circ} \mathrm{C}$ under a nitrogen atmosphere. The solution was stirred and $t$-butyl bromoacetate $(21.8 \mathrm{~mL}, 145$ mmole was introduced. The reaction was complete after $20 \mathrm{~h}$ as evidenced by HPLC. ${ }^{b}$ Aqueous $\mathrm{KHSO}_{4}(10 \%, 640 \mathrm{~mL})$ was added to the stirring reaction mixture to give a precipitate. The mixture was filtered and the filtrate was evaporated under vacuum at $40{ }^{\circ} \mathrm{C}$ to remove $\mathrm{CH}_{3} \mathrm{CN}$. The aqueous solution $(\mathrm{pH}$ 2.3) was washed with heptane $(400 \mathrm{~mL})$. The aqueous layer was basified with $5 \mathrm{~N}$ aqueous $\mathrm{NH}_{4} \mathrm{OH}$ to $\mathrm{pH}$ 10.6. The milky solution was extracted with $\mathrm{CH}_{2} \mathrm{Cl}_{2}(3 \mathrm{x}$ $350 \mathrm{~mL})$. The combined organic extracts were washed with brine $(350 \mathrm{~mL})$ and dried by stirring overnight over $\mathrm{MgSO}_{4}$. The mixture was filtered and the filtrate was evaporated on a rotary evaporator. The resulting oil was redissolved in EtOAc $(200 \mathrm{~mL})$ and filtered through a pad of silica gel $(70 \mathrm{~g})$. The product was eluted with EtOAc $(600 \mathrm{~mL})$ and the solvent was evaporated to provide $63.6 \mathrm{~g}$ of aminodiester 5a (yield 92\%). ${ }^{1} \mathrm{H}$ NMR $\left(270 \mathrm{MHz}, \mathrm{CDCl}_{3}\right) \delta, 1.0(\mathrm{~s}, 6 \mathrm{H}), 1.3-$ $1.4(\mathrm{~m}, 4 \mathrm{H}), 1.5(\mathrm{~s}, 9 \mathrm{H}), 1.6-1.8(\mathrm{~m}, 2 \mathrm{H}), 3.2(\mathrm{~s}, 2 \mathrm{H}), 3.7(\mathrm{~s}, 3 \mathrm{H}), 4.3-4.4(\mathrm{~m}$,

\footnotetext{
${ }^{9}$ HPLC method same as in footnote $1: \mathrm{R}_{\mathrm{t}}$ product $16.0 \mathrm{~min}$.
} 
$1 \mathrm{H}), 5.1(\mathrm{~s}, 2 \mathrm{H}), 5.3(\mathrm{~m}, 1 \mathrm{H}), 7.4(\mathrm{~s}, 5 \mathrm{H}) .{ }^{13} \mathrm{C} \mathrm{NMR}\left(68 \mathrm{MHz}, \mathrm{CDCl}_{3}\right) \delta, 19.6$, 26.0, 28.0, 33.0, 40.1, 44.5, 51.5, 52.3, 53.4, 53.6, 66.9, 81.6, 127.8 128.0, 128.4, $136.1,155.8,171.2,172.8$. IR (neat) $3390,1730 \mathrm{~cm}^{-1} .[\alpha]_{\mathrm{D}}=-10(\mathrm{c}=1$, $\mathrm{CH}_{3} \mathrm{OH}$ ). $\mathrm{MS}$ (ESI) $\mathrm{M}+\mathrm{H}=437, \mathrm{M}-\mathrm{H}=435,2 \mathrm{M}+\mathrm{H}=973$. Anal. calcd for $\mathrm{C}_{23} \mathrm{H}_{36} \mathrm{~N}_{2} \mathrm{O}_{6}$ : C, 63.28; H, 8.31; N, 6.42; Found: C, 63.23; H, 8.49; N, 6.66.

$N^{6}$-[2-(1,1-Dimethylethoxy)-2-oxoethyl]-6,6-dimethyl- $N^{2}-[($ phenylmethoxy)-carbonyl]-L-lysine, monohydrochloride ( $\mathrm{HCl}$ salt of $\mathbf{5 b})$.

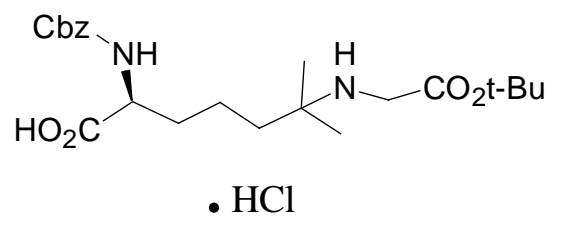

A solution of $\mathrm{LiOH}$ monohydrate $(5.3 \mathrm{~g}, 136 \mathrm{mmoles})$ in $\mathrm{H}_{2} \mathrm{O}(160 \mathrm{~mL})$ was added to a solution of aminodiester $\mathbf{5 a}(53.9 \mathrm{~g}, 124 \mathrm{mmole})$ in THF $(780 \mathrm{~mL})$ and water $(100 \mathrm{~mL})$ stirring at $0{ }^{\circ} \mathrm{C}$ under nitrogen gas atmosphere. After $3.5 \mathrm{~h}, 1 \mathrm{~N} \mathrm{HCl}(20$ $\mathrm{mL}$ ) was added to adjust the $\mathrm{pH}$ to 10.4 . The mixture was concentrated under vacuum to a cloudy aqueous solution. It was treated with $1 \mathrm{~N} \mathrm{HCl}(180 \mathrm{~mL})$ to bring the $\mathrm{pH}$ to 2.6. Solid $\mathrm{NaCl}(80 \mathrm{~g})$ was added to this solution. The resulting milky aqueous solution was extracted with $\mathrm{CH}_{2} \mathrm{Cl}_{2}(3 \times 350 \mathrm{~mL})$. The organic solution was dried over $\mathrm{MgSO}_{4}$, filtered and evaporated under vacuum to furnish $57.1 \mathrm{~g}$ (yield 93.4\%) of the hydrochloride salt of $\mathbf{5 b} .{ }^{1} \mathrm{H}$ NMR $\left(270 \mathrm{MHz}, \mathrm{CDCl}_{3}\right)$ $\delta, 1.4(\mathrm{~s}, 6 \mathrm{H}), 1.5(\mathrm{~m}, 2 \mathrm{H}), 1.6(\mathrm{~s}, 9 \mathrm{H}), 1.9(\mathrm{br} \mathrm{s}, 4 \mathrm{H}), 3.8(\mathrm{br} \mathrm{s}, 2 \mathrm{H}), 4.4(\mathrm{~m}, 1$ $\mathrm{H}), 5.2(\mathrm{~s}, 2 \mathrm{H}), 6.2-6.23(\mathrm{~d}, 1 \mathrm{H}, \mathrm{J}=9.6 \mathrm{~Hz}), 7.4$ (br s, $5 \mathrm{H}), 9.7$ (br s, $1 \mathrm{H}) .{ }^{13} \mathrm{C}$ NMR $\left(68 \mathrm{MHz}, \mathrm{CDCl}_{3}\right) \delta, 19.0,22.8,23.0,27.8,32.6,38.3,53.4,54.0,60.5$, $66.5,84.4,127.8,127.9,128.3,136.7,156.0,165.9,175.5 .[\alpha]_{\mathrm{D}}=-7.0(\mathrm{c}=1.0$, $\left.\mathrm{CH}_{3} \mathrm{OH}\right)$.

(S)-Hexahydro-2,2-dimethyl-7-oxo-6-[[(phenylmethoxy)carbonylamino] 1H-azepine-1-acetic acid, 1,1-dimethylethyl ester (6a).

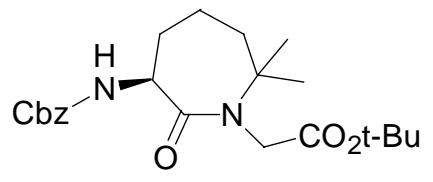


1-Hydroxybenzotriazole monohydrate (HOBT, $19.9 \mathrm{~g}, 130 \mathrm{mmol}$ ) was added to a solution of aminoacid hydrochloride $\mathbf{5 b}(51.8 \mathrm{~g}, 113 \mathrm{mmole})$ in $\mathrm{CH}_{3} \mathrm{CN}(1.051)$ at $20{ }^{\circ} \mathrm{C}$ under a nitrogen atmosphere. Diisopropylethyl amine (21.6 mL, 124 mmole) was added dropwise and then 1-(3dimethylaminopropyl)-3-ethylcarbodiimide hydrochloride (EDC, $26.0 \mathrm{~g}$, 136 mmole) was introduced. After $2 \mathrm{~h}$ HPLC ${ }^{\mathbb{1 0}}$ analysis indicated the completion of the reaction. The orange red solution was concentrated at 35 ${ }^{\circ} \mathrm{C}$. The residue was taken up in EtOAc $(700 \mathrm{~mL})$ and washed with $\mathrm{HCl}$ $(1 \mathrm{~N}, 300 \mathrm{~mL})$, aqueous $\mathrm{NaHCO}_{3}(2 \times 300 \mathrm{ml})$ and brine $(200 \mathrm{~mL})$. The solution was dried over $\mathrm{MgSO}_{4}$, filtered and concentrated in vacuum. The dark red oil was dissolved in a mixture $(1: 8)$ of EtOAc and hexane $(500 \mathrm{~mL})$ and filtered through a pad of silica gel $(150 \mathrm{~g})$. The product was eluted with mixture $(1: 8)$ of EtOAc and hexane $(5 \times 500 \mathrm{~mL})$. The first four fractions were combined and solvent was removed under vacuum to obtain $42.0 \mathrm{~g}$ of product 6a (yield 92\%). ${ }^{1} \mathrm{H}$ NMR $\left(270 \mathrm{MHz}, \mathrm{CDCl}_{3}\right) \delta, 1.3(\mathrm{~s}, 3 \mathrm{H}), 1.4(\mathrm{~s}, 3$ $\mathrm{H}), 1.5(\mathrm{~s}, 9 \mathrm{H}), 1.5-1.7(\mathrm{~m}, 1 \mathrm{H}), 1.8-2.0(\mathrm{~m}, 4 \mathrm{H}), 2.1-2.2(\mathrm{~m}, 1 \mathrm{H})$, $3.8-4.3(\mathrm{AB} \mathrm{q}, 2 \mathrm{H}, \mathrm{J}=18 \mathrm{~Hz}), 4.6-4.8(\mathrm{~m}, 1 \mathrm{H}), 5.1(\mathrm{~s}, 2 \mathrm{H}), 6.2(\mathrm{~m}, 1$ $\mathrm{H}), 7.4$ (br s, $5 \mathrm{H}) .{ }^{13} \mathrm{C}$ NMR $\left(68 \mathrm{MHz}, \mathrm{CDCl}_{3}\right) \delta$, 20.1,27.9, 28.0, 30.4, 30.5. 30.7, 30.8, 40.0, 47.5, 53.2, 55.8, 58.8, 60.4, 66.5, 81.4, 127.9, 128.4, 136.7, 155.5, 169.2, 172.6, . IR (KBr) 3405, 3335, 1724, $1740 \mathrm{~cm}^{-1}$. Anal. calcd for $\mathrm{C}_{22} \mathrm{H}_{32} \mathrm{~N}_{2} \mathrm{O}_{5}$ : C, 65.32; H, 7.97; N, 6.93; Found: C, 65.12; H, 8.02; $\mathrm{N}, 6.79 .[\alpha]_{\mathrm{D}}=-16.0\left(\mathrm{c}=1.0, \mathrm{CH}_{3} \mathrm{OH}\right)$.

(S)-6-Aminohexahydro-2,2-dimethyl-7-oxo-1H-azepine-1-acetic acid, 1,1dimethylethyl ester $(\boldsymbol{6} \boldsymbol{b})$.

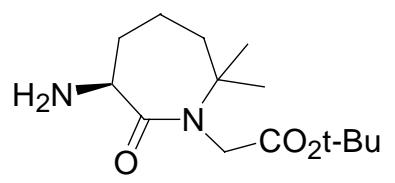

$\mathrm{Pd}(\mathrm{OH})_{2}(0.395 \mathrm{~g})$ was added to a solution of $6 \mathbf{a}(3.95 \mathrm{~g}, 9.7 \mathrm{mmol})$ in $50 \mathrm{~mL}$ $\mathrm{MeOH}$. The reaction mixture was stirred under hydrogen atmosphere from a balloon. The hydrogenolysjs was complete after $4 \mathrm{~h}$ (TLC: Silica gel, EtOAc, $\mathrm{R}_{\mathrm{f}}$ of $\mathbf{6 b}=0.1$ and $\mathbf{6 a}=0.8)$. The catalyst was filtered through a Celite pad and the

\footnotetext{
${ }^{10}$ HPLC method same as in footnote 1: $\mathrm{R}_{\mathrm{t}}$ product 6a $26.3 \mathrm{~min}$., $5 \mathrm{~b} 14.1 \mathrm{~min}$ and HOBT $5.0 \mathrm{~min}$.

${ }^{11}$ HPLC method same as in footnote $1: \mathrm{R}_{\mathrm{t}}$ of $\mathbf{6} \mathbf{b}=10.7 \mathrm{~min}$.
} 
filtrate was evaporated. The residue was taken up in EtOAc and evaporated to remove residual $\mathrm{MeOH}$. The crystalline prduct was dried under vacuum to give $2.59 \mathrm{~g}$ (yield $97.9 \%$ ) of $\mathbf{6 b}, \mathrm{mp} 73-75^{\circ} \mathrm{C}$ (recrystallized from EtOAc/hexane; m.p. 84-85 $\left.{ }^{\circ} \mathrm{C}\right) . \mathrm{HPLC}^{11}$ AP $(205 \mathrm{~nm})$ 98.0, chiral HPLC ${ }^{12}$ ee $(210 \mathrm{~nm})$ 95.5. ${ }^{1} \mathrm{H}$ NMR $\left(270 \mathrm{MHz}, \mathrm{CDCl}_{3}\right) \delta, 1.3(\mathrm{~s}, 3 \mathrm{H}), 1.4(\mathrm{~s}, 3 \mathrm{H}), 1.5(\mathrm{~s}, 9 \mathrm{H}), 1.5-1.7(\mathrm{~m}, 1 \mathrm{H}), 1.8$ - $1.95(\mathrm{~m}, 5 \mathrm{H}), 2.3$ (br s, $2 \mathrm{H}), 3.7-3.8(\mathrm{dd}, 1 \mathrm{H}, \mathrm{J}=4 \mathrm{~Hz}, 13 \mathrm{~Hz}), 3.9-4.3(\mathrm{AB}$ q, $2 \mathrm{H}, \mathrm{J}=17 \mathrm{~Hz}) .{ }^{13} \mathrm{C} \mathrm{NMR}\left(68 \mathrm{MHz}, \mathrm{CDCl}_{3}\right) \delta, 20.0,27.8,28.0,30.0,32.2$, 40.0, 53.4, 57.1, 58.2, 80.9, 169.4, 176.6. IR (KBr) 3500, 1742, $1620 \mathrm{~cm}^{-1} . \mathrm{mp} 73$ $-75^{\circ} \mathrm{C}$. MS (ESI) $\mathrm{M}+\mathrm{H}=271,2 \mathrm{M}+\mathrm{H}=541$. Anal. calcd for $\mathrm{C}_{14} \mathrm{H}_{26} \mathrm{~N}_{2} \mathrm{O}_{3}: \mathrm{C}$, $61.61 ; \mathrm{H}, 9.71 ; \mathrm{N}, 10.27 ; \mathrm{H}_{2} \mathrm{O}$ 0.92; Found: C, 61.28; H, 9.68; N, 10.09; $\mathrm{H}_{2} \mathrm{O} 0.71$ (K.F.). $[\alpha]_{D}=+7.3(\mathrm{c}=1.0$, EtOAc $)$.

(S)-6-Aminohexahydro-2,2-dimethyl-7-oxo-1H-azepine-1-acetic acid, 1,1dimethylethyl ester, methanesulfonate $(1: 1)(\boldsymbol{6 c})$.

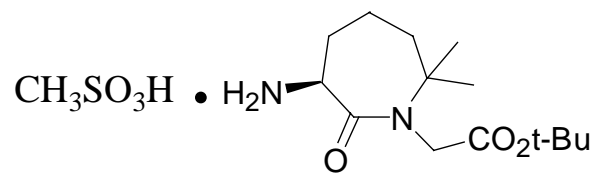

A solution of methanesulfonic acid in EtOAc $(1.0 \mathrm{M}, 2.05 \mathrm{~mL}, 2.05 \mathrm{mmol})$ was added to a solution of $\mathbf{6 b}(0.541 \mathrm{~g}, 2.0 \mathrm{mmol}$, ee $95.5 \%)$ in $4 \mathrm{~mL}$ of EtOAc at ambient temperature under an argon atmosphere. Seed crystals of the salt $\mathbf{6 c}$ were added and the mixture was gently stirred magnetically in an ice-bath. Copious crystals were obtained within a few minutes. After $3 \mathrm{~h}$ the solid was filtered and the residue in the flask was transferred to the funnel with a portion of the first filtrate. The product was washed with $2 \mathrm{ml}$ of ice-cold EtOAc and dried under vacuum for $1.5 \mathrm{~h}$ to give salt $\mathbf{6 c}(0.556 \mathrm{~g}, 75.9 \%$ yield) as birefringent crystals, $\mathrm{mp}$ $151{ }^{\circ} \mathrm{C}$ (dec.), chiral HPLC ee $\left(210 \mathrm{~nm}, 99.5 .{ }^{12}{ }^{1} \mathrm{H} \mathrm{NMR}\left(270 \mathrm{MHz}, \mathrm{CDCl}_{3}\right) \delta, 1.3\right.$ $(\mathrm{s}, 3 \mathrm{H}), 1.4(\mathrm{~s}, 3 \mathrm{H}), 1.5(\mathrm{~s}, 9 \mathrm{H}), 1.5-1.7(\mathrm{~m}, 1 \mathrm{H}), 1.8-1.95(\mathrm{~m}, 5 \mathrm{H}), 2.3$ (br s, $2 \mathrm{H}), 3.7-3.8(\mathrm{dd}, 1 \mathrm{H}, \mathrm{J}=4 \mathrm{~Hz}, 13 \mathrm{~Hz}), 3.9-4.3(\mathrm{AB} \mathrm{q}, 2 \mathrm{H}, \mathrm{J}=17 \mathrm{~Hz}) .{ }^{13} \mathrm{C}$ NMR $\left(68 \mathrm{MHz} \mathrm{CDCl}_{3}\right) \delta, 20.0,27.8,28.0,30.0,32.2,40.0,53.4,57.1,58.2$, 80.9, 169.4, 176.6. IR (KBr) 3500, 1742, $1620 \mathrm{~cm}^{-1}$. mp $73-75^{\circ} \mathrm{C}$. MS (ESI) M

\footnotetext{
${ }^{12}$ Chiral HPLC for azepinone 6b. Chiral column Crownpak CR+, 4.0 x $150 \mathrm{~mm}, 5 \mu \mathrm{m}$, mobile phase 85:15 aqueous $\mathrm{HClO}_{4}(\mathrm{pH} \mathrm{1.5}) / \mathrm{MeOH}$, flow rate $1.0 \mathrm{ml} / \mathrm{min}$., UV wavelength $210 \mathrm{~nm}$.
} 
$+\mathrm{H}=271,2 \mathrm{M}+\mathrm{H}=$ 541. Anal. calcd for $\mathrm{C}_{14} \mathrm{H}_{26} \mathrm{~N}_{2} \mathrm{O}_{3}: \mathrm{C}, 61.61 ; \mathrm{H}, 9.71 ; \mathrm{N}$, 10.27; $\mathrm{H}_{2} \mathrm{O}$ 0.92; Found: C, 61.28; H, 9.68; N, 10.09; $\mathrm{H}_{2} \mathrm{O} 0.71$ (K.F.). $[\alpha]_{\mathrm{D}}=+$ $7.3(\mathrm{c}=1.0$, EtOAc).

This salt was converted back to the free base $\mathbf{6 b}$ in nearly quantitative yield by neutralization of its aqueous solution with $\mathrm{NaOH}$, extraction with $\mathrm{CH}_{2} \mathrm{Cl}_{2}$, drying $\left(\mathrm{MgSO}_{4}\right)$ and evaporation of the solvent.

Part II: $\quad$ Synthesis of (S)- $\alpha$-aminoazepinone $\mathbf{6 b}$ via dynamic resolution of racemic $\alpha$-aminoazepinone $\mathbf{1 5 b}$.

N-(1,1-Dimethyl-2-propynyl)glycine, 1,1-dimethylethyl ester (8).

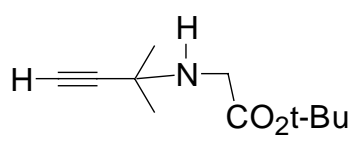

t-Butylbromoacetate $(98 \%, 37.1 \mathrm{~g}, 186.5 \mathrm{mmol})$ was added to a solution of wet 1,1-dimethylpropargyl amine $(90 \%, 43.0 \mathrm{~g}, 466 \mathrm{mmol})$ in THF $(100 \mathrm{~mL})$ and the mixture was stirred at $20{ }^{\circ} \mathrm{C}$. The reaction was complete after $20 \mathrm{~h}$ (TLC: Silica gel, EtOAc/hexane 1:4, $\mathrm{R}_{\mathrm{f}}$ of $\mathbf{8} 0.4$ and t-butylbromoacetate 0.6 , visualized by $\mathrm{UV}$ and $\mathrm{p}$-anisaldehyde/heat). Solvent was evaporated on a rotary evaporator and the resulting mixture of white solid ( $\mathrm{HBr}$ salt of 1,1-dimethylpropargyl amine) and oil was treated with hexane $(50 \mathrm{~mL})$ and filtered. The filter cake was washed with hexane $(150 \mathrm{~mL})$ and the filtrate was extracted with $10 \% \mathrm{KHSO}_{4}(150 \mathrm{~mL})$. The $\mathrm{pH}$ of aqueous layer was 3.5. The organic layer was extracted further with $10 \%$ $\mathrm{KHSO}_{4}(3 \times 60 \mathrm{~mL})$ until the $\mathrm{pH}$ of the aqueous layer was below 1.5. The aqueous extracts were combined and washed with hexane $(2 \times 50 \mathrm{~mL})$. Methyl-t-butyl ether (MTBE, $100 \mathrm{~mL}$ ) was added the aqueous layer stirred at $20^{\circ} \mathrm{C}$ and conc. $\mathrm{NH}_{4} \mathrm{OH}(19 \mathrm{~mL})$ was added dropwise to $\mathrm{pH} 10.5$. The aqueous layer was separated and extracted with MTBE $(3 \times 50 \mathrm{~mL})$. The organic extracts were 
combined and washed with brine $(20 \mathrm{~mL})$ and dried by stirring over $\mathrm{MgSO}_{4}$ for $0.5 \mathrm{~h}$. The mixture was filtered and the solvent was evaporated under vacuum. The oily product was dried under pump vacuum to give $34.75 \mathrm{~g}$ (yield 94.6\%) of ester 8. ${ }^{1} \mathrm{H}$ NMR (270 MHz, $\mathrm{CDCl}_{3}$ ) $\delta, 1.39$ (s, 6H), 1.48 (s, 9H), 1.78 (br s, 1H), $2.28(\mathrm{~s}, 1 \mathrm{H}), 3.42(\mathrm{~s}, 2 \mathrm{H}) ;{ }^{13} \mathrm{C} \mathrm{NMR}\left(\mathrm{CDCl}_{3}, 68 \mathrm{MHz}\right) \delta, 28.6,29.9,47.4,49.8$, 70.8, 81.7, 172.0; IR $\left(\mathrm{CH}_{2} \mathrm{Cl}_{2}\right.$ film) 3302, $1736 \mathrm{~cm}^{-1} ; \mathrm{MS}$ (ESI) $\mathrm{M}+\mathrm{H}=198$; Anal. calcd for $\mathrm{C}_{11} \mathrm{H}_{19} \mathrm{~N}_{1} \mathrm{O}_{2}$ : C, 66.97; H, 9.71; N, 7.10. Found: C, 66.68; H, 9.67; N, 7.07.

(Z)-3-Bromo-2-[[(1,1-dimethylethoxy)carbonyl]amino]-2-propenoic acid, methyl ester (11).

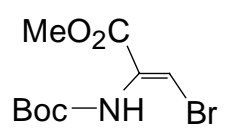

A dry, 1-1 flask equipped with a magnetic stir bar and an argon inlet was charged with N-BOC-L-serine methyl ester 9 (50.0 g, $227 \mathrm{mmol})$ and anhydrous $\mathrm{CH}_{2} \mathrm{Cl}_{2}$ $(500 \mathrm{~mL})$. The mixture was stirred until homogeneous. The solution was cooled to $0^{\circ} \mathrm{C}$, and methanesulfonyl chloride $(18 \mathrm{~mL}, 232 \mathrm{mmol})$ was added over 2-3 min. Triethylamine $(95 \mathrm{~mL}, 681 \mathrm{mmol})$ was added slowly over $30 \mathrm{~min}$ such that the internal temperature never exceeded $6{ }^{\circ} \mathrm{C}$. The mixture was stirred at $0{ }^{\circ} \mathrm{C}$ for 30 min and then was allowed to warm to room temperature over $1 \mathrm{~h}$. After stirring for $30 \mathrm{~min}$. the reaction was complete by TLC (silica gel, 1:1 hexane:EtOAc; $9 \mathrm{Rf}$ $=0.28,10 \mathrm{Rf}_{\mathrm{f}}=0.74 ; \mathrm{Rf}$ of intermediate mesylate $=0.36 ; \mathrm{KMnO}_{4}$ for visualization). The mixture was washed with $0.5 \mathrm{M} \mathrm{KHSO}_{4}(200 \mathrm{ml}$ diluted with $75 \mathrm{ml} \mathrm{H} 2 \mathrm{O}$ and $2 \times 200 \mathrm{ml}$ without dilution), sat. $\mathrm{NaHCO}_{3}$, (200 mL), and brine $(200 \mathrm{~mL})$. The organic layer was dried $\left(\mathrm{MgSO}_{4}\right)$ and concentrated under vacuum to approximately $250 \mathrm{~mL}$. The orange solution was diluted with anhydrous 
$\mathrm{CH}_{2} \mathrm{Cl}_{2}$ to $500 \mathrm{~mL}$ and charged into a dry flask equipped with a magnetic stir bar and an argon inlet. N-Bromosuccinimide (38.4 g, $216 \mathrm{mmol}$ ) was added and the mixture was stirred for $1 \mathrm{~h}$ at room temperature. The mixture was cooled to $0{ }^{\circ} \mathrm{C}$ and triethylamine $(16 \mathrm{~mL}, 114 \mathrm{mmol})$ was added slowly over $10 \mathrm{~min}$ such that the internal temperature remained below $6^{\circ} \mathrm{C}$. Stirring was continued for $1 \mathrm{~h}$. The mixture was concentrated in vacuum to an oil/solid mixture, which was concentrated from MTBE $(2 \times 100 \mathrm{~mL})$ to remove $\mathrm{CH}_{2} \mathrm{Cl}_{2}$. The residue was dissolved in MTBE (500 mL) and washed successively with $0.5 \mathrm{M} \mathrm{KHSO}_{4}(2 \mathrm{x}$ $100 \mathrm{~mL})$, half-saturated $\mathrm{NaHCO}_{3}(2 \times 100 \mathrm{~mL})$ and brine $(100 \mathrm{~mL})$. The solution was dried with $\mathrm{MgSO}_{4}$, filtered and concentrated under vacuum such that about 30 $\mathrm{mL}$ MTBE still remained in the product. The solution was stirred mechanically and cooled to $0{ }^{\circ} \mathrm{C}$. Hexane was added slowly to cloudiness and then seed crystals of 11 were added; the product began to crystallize. The remaining hexane (900 $\mathrm{mL}$ total) was added slowly over $20 \mathrm{~min}$. The suspension was cooled slowly over $1 \mathrm{~h}$ to $-20{ }^{\circ} \mathrm{C}$ and then placed in a $-20{ }^{\circ} \mathrm{C}$ freezer for $5 \mathrm{~h}$. The mixture was filtered cold, and the solids were washed with $3 \% \mathrm{MTBE} / \mathrm{hexane}(2 \times 40 \mathrm{~mL})$ and airdried for $30 \mathrm{~min}$ to provide $11\left(47.5 \mathrm{~g}, 75 \%\right.$ yield; $\left.\mathrm{mp} 59^{\circ} \mathrm{C}\right)$ as a white solid. The mother liquor was concentrated to an oil which was crystallized from $6 \mathrm{~mL}$ MTBE and $180 \mathrm{~mL}$ hexane as above to provide a second crop of $\mathbf{1 1}$ (3.8 $\mathrm{g}, 6 \%$ yield; total yield $81 \%) .{ }^{1} \mathrm{H}$ NMR $\left(270 \mathrm{MHz} \mathrm{CDCl}_{3}\right) \delta, 1.48(\mathrm{~s}, 9 \mathrm{H}), 3.82(\mathrm{~s}, 3 \mathrm{H}), 6.22$ (br s, $1 \mathrm{H}), 6.88(\mathrm{~s}, 1 \mathrm{H}) ;{ }^{13} \mathrm{C} \mathrm{NMR}\left(68 \mathrm{MHz}, \mathrm{CDCl}_{3}\right) \delta, 28.2,53.0,81.9,109.3,132.4$, 151.8, 163.0; IR (KBr) 3232, 1739, $1715 \mathrm{~cm}^{-1}$; MS (ESI) $\mathrm{M}+\mathrm{H}=280, \mathrm{M}-\mathrm{H}=$ 278; mp $59^{\circ} \mathrm{C}$; Anal. calcd for $\mathrm{C}_{9} \mathrm{H}_{14} \mathrm{NO}_{4} \mathrm{Br} ; \mathrm{C}, 38.53 ; \mathrm{H}, 5.05 ; \mathrm{N}, 5.00 ; \mathrm{Br} 28.53$. Found: C, 38.46, H, 5.09; N, 4.87; Br, 28.86. ${ }^{13}$

\footnotetext{
${ }^{13}$ (a). Miossec; R. Danion-Bougot; D. Danion, Synthesis, 1994, 1171. (b). Yamada, M.; Nakao, K.; Fukui, T.; Nunami, K. Tetrahedron, 1996, 52, 5751.
} 
(Z)-6-[[(1,1-Dimethylethoxy)acetyl]amino]-2-[[(1,1-dimethylethoxy)-

carbonyl]amino]-6-methyl-2-hepten-4-ynoic acid, methyl ester, methanesulfonic acid salt (12a).

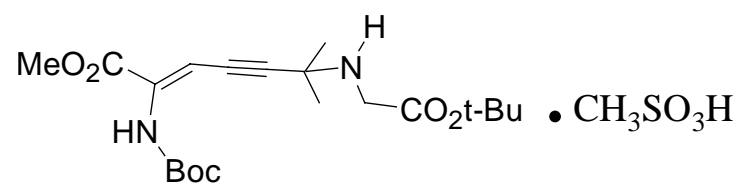

Triethylamine (600 mL) and ester 8 ( $74 \mathrm{~g}, 375 \mathrm{mmol})$ were added consecutively to bromide $11(100 \mathrm{~g}, 357 \mathrm{mmol})$ at $15^{\circ} \mathrm{C}$. The contents were stirred to homogeneity and then $\mathrm{Pd}\left(\mathrm{Ph}_{3} \mathrm{P}\right)_{4}(1 \mathrm{~g}, 0.9 \mathrm{mmol})$ and $\mathrm{CuI}(1.44 \mathrm{~g}, 7.6 \mathrm{mmol})$ were added. ${ }^{13 \mathrm{a}} \mathrm{In}$ $10 \mathrm{~min}$, the reaction temperature rose slowly to $22^{\circ} \mathrm{C}$. The mixture was cooled to $15{ }^{\circ} \mathrm{C}$. After $2 \mathrm{~h}$ additional $\mathrm{Pd}\left(\mathrm{Ph}_{3} \mathrm{P}\right)_{4}(1 \mathrm{~g}, 0.9 \mathrm{mmol})$ was added, and the reaction mixture was stirred for $1 \mathrm{~h}$. After $8.5 \mathrm{~h}$ the mixture was diluted with MTBE (600 $\mathrm{mL}$ ) and stirred for $30 \mathrm{~min}$. The mixture was filtered through a medium-frit funnel, and the solids were washed with MTBE $(3 \times 100 \mathrm{~mL})$. The filtrate was concentrated in vacuum to an oil. The oil was dissolved in MTBE $(700 \mathrm{~mL})$, and the solution was extracted with $1 \mathrm{M}$ aqueous $\mathrm{KHSO}_{4}(4 \times 200 \mathrm{~mL} ; 2$ x $100 \mathrm{~mL})$ while performing TLC analyses (40\% EtOAc/hexane; silica gel plate) of the MTBE layer after each extraction to ensure adequate extraction of $\mathbf{1 2}\left(\mathrm{R}_{\mathrm{f}}=0.28\right)$. The aqueous extracts were combined and cooled to $10{ }^{\circ} \mathrm{C}$. The $\mathrm{pH}$ was adjusted to 8 with $50 \%$ aqueous $\mathrm{NaOH}(50 \mathrm{~mL})$ while maintaining the internal temperature at $<25{ }^{\circ} \mathrm{C}$. The resulting aqueous/oily mixture was diluted with saturated aqueous $\mathrm{NaCl}(200 \mathrm{~mL})$ and then extracted with EtOAc $(3 \mathrm{x} 400 \mathrm{~mL})$. The combined EtOAc layers were treated with $\mathrm{MgSO}_{4}$ and decolorizing carbon (Norit A; $21 \mathrm{~g}$ ) and stirred for $30 \mathrm{~min}$. The mixture was filtered through Celite, and the solids were washed with EtOAc $(2 \times 250 \mathrm{~mL})$. The filtrate was concentrated in vacuum to give the enyne ester $\mathbf{1 2}$ as an oil. The oil was dissolved in IPA $(250 \mathrm{~mL})$ and 
concentrated in vacuum to an oil (167 g). The oil was dissolved in isopropyl alcohol (IPA, 2.1 L) by warming and then the solution was cooled to $20{ }^{\circ} \mathrm{C}$. With stirring, methanesulfonic acid $(12.3 \mathrm{~mL}, 190 \mathrm{mmol})$ was added slowly over 15 min. Seed crystals of 12a were added, and the mixture was stirred for $5 \mathrm{~min}$; the product crystallized. Additional methanesulfonic acid $(10.0 \mathrm{~mL}, 154 \mathrm{mmol})$ was added over approximately $5 \mathrm{~min}$. After $5 \mathrm{~h}$ the mixture was filtered and the solid was washed with IPA ( 2 × $250 \mathrm{~mL})$ and air-dried overnight to give $140 \mathrm{~g}$ of 12a (yield 79\%) as off-white crystals, mp 156-58 ${ }^{\circ} \mathrm{C}$ dec, HPLC AP $100 .^{14}$ The combined filtrates were concentrated to $450 \mathrm{~g}$ of a solid/liquid mixture. The mixture was heated to $60{ }^{\circ} \mathrm{C}$ with stirring to dissolve all solids and the heating bath was removed. Seeds of $\mathbf{1 2 a}$ were added at $50{ }^{\circ} \mathrm{C}$ and the mixture allowed to cool and stir overnight. The resulting slurry was filtered and the solid was washed with 50:50 IPA/MTBE ( $2 \times 125 \mathrm{~mL})$ and air-dried for $2.5 \mathrm{~h}$ to yield a second crop of 12a (15.2 g, yield 9\%; HPLC AP 100; combined yield 88\%) as white crystals. ${ }^{1} \mathrm{H}$ NMR $\left(270 \mathrm{MHz}, \mathrm{CD}_{3} \mathrm{OD}\right) \delta, 1.48(\mathrm{~s}, 9 \mathrm{H}), 1.53(\mathrm{~s}, 9 \mathrm{H}), 1.71(\mathrm{~s}, 6 \mathrm{H}), 2.68(\mathrm{~s}$, $3 \mathrm{H}), 3.79$ (s, 3H), $4.06(\mathrm{~s}, 2 \mathrm{H}), 6.12(\mathrm{~s}, 1 \mathrm{H}) ; 13 \mathrm{C} \mathrm{NMR}\left(68 \mathrm{MHz}, \mathrm{CD}_{3} \mathrm{OD}\right) \delta, 26.2$, $28.3,28.5,39.3,45.4,53.0,55.9,81.5,82.7,85.1,96.7,105.5,137.9,152.8$, 165.5, 166.9; IR (KBr) 3236, 1740, $1615 \mathrm{~cm}^{-1}$; MS (ESI) $\mathrm{M}+\mathrm{H}=397, \mathrm{M}-\mathrm{H}=$ 395; mp 156-58 ${ }^{\circ} \mathrm{C}$ (dec., effervescence); Anal. Calcd for $\mathrm{C}_{20} \mathrm{H}_{32} \mathrm{~N}_{2} \mathrm{O}_{6} \bullet 1.0$ $\mathrm{CH}_{3} \mathrm{SO}_{3} \mathrm{H}: \mathrm{C}, 51.21 ; \mathrm{H}, 7.37 ; \mathrm{N}, 5.69 ; \mathrm{S}, 6.51$. Found: C, 51.11; H, 7.21; N, 5.56; S, 6.59.

\footnotetext{
${ }^{14}$ HPLC method same as in footnote 1 at wavelength $220 \mathrm{~nm} . \mathrm{R}_{\mathrm{t}} \mathbf{1 1} 18.2 \mathrm{~min}$ and $\mathbf{1 2} 15.1 \mathrm{~min}$.
} 
1,7-Diaza-6,6-dimethyl-1,2,8-octanetricarboxylic acid, 2-methyl-1,8-

bis(1,1-dimethylethyl) ester, methanesulfonic acid salt (13c).

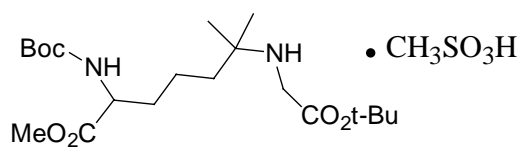

Rh-C (5\%, 13.5 g) was added to a solution of $12 \mathrm{a}(135.2 \mathrm{~g}, 276.5 \mathrm{mmol})$ in $\mathrm{MeOH}$ $(1350 \mathrm{~mL})$ at $0{ }^{\circ} \mathrm{C}$. The vessel was purged with $\mathrm{H}_{2}$ and the mixture was then stirred vigorously under 1 atmosphere of $\mathrm{H}_{2}$ gas. After $7 \mathrm{~h}$, the reaction was allowed to warm to room temperature over $30 \mathrm{~min}$. The reaction was filtered through Celite, and the Celite was washed with $\mathrm{MeOH}(3 \times 200 \mathrm{~mL})$. The combined filtrate was concentrated to an oil, which was dissolved in IPA (200 $\mathrm{mL}$ ) and evaporated again to give a solid (136.86 g). The solid was redissolved in IPA $(400 \mathrm{~mL})$ with stirring at $50{ }^{\circ} \mathrm{C}$ to give a hazy solution that was allowed to cool to $20{ }^{\circ} \mathrm{C}$, and then MTBE (500 mL) was added. Seed crystals of 13a were added, and the product began to crystallize. Additional MTBE $(600 \mathrm{~mL})$ was added slowly over $20 \mathrm{~min}$ and the slurry was stirred for $4 \mathrm{~h}$. The slurry was filtered, and the product was washed with MTBE (200 mf and air-dried overnight to provide 13a [118.2 $\mathrm{g}$, yield 86\%; AP $(210 \mathrm{~nm}) 100]^{15}$ as a white solid. The mother liquor was concentrated and the solid was recrystallized with the same procedure as above using IPA $(56 \mathrm{~mL})$ and MTBE $(150 \mathrm{~mL})$ to provide a second crop of 13a (9.9 g, yield 7\%; AP 100, total yield 93\%). ${ }^{1} \mathrm{H}$ NMR $(270 \mathrm{MHz}$, $\left.\mathrm{CD}_{3} \mathrm{OD}\right) \delta, 1.33(\mathrm{~s}, 6 \mathrm{H}), 1.43(\mathrm{~s}, 9 \mathrm{H}), 1.52(\mathrm{~s}, 9 \mathrm{H}), 1.4-1.85$ (m, 6H), 2.69 (s, $3 \mathrm{H}), 3.7(\mathrm{~s}, 3 \mathrm{H}), 3.87(\mathrm{~s}, 2 \mathrm{H}), 4.12(\mathrm{~m}, 1 \mathrm{H}) ;{ }^{13} \mathrm{C} \mathrm{NMR}\left(68 \mathrm{MHz}, \mathrm{CD}_{3} \mathrm{OD}\right) \delta, 21.1$, 23.2, 28.2, 28.6, 32.6, 38.4, 39.5, 43.3, 52.6, 54.5, 61.1, 80.6, 85.1, 158.1, 167.2, 174.6; IR (KBr) 3386, 1750, 1724, $1709 \mathrm{~cm}^{-1}$; MS (ESI) $\mathrm{M}+\mathrm{H}=403, \mathrm{M}-\mathrm{H}=$

\footnotetext{
${ }^{15}$ HPLC method same as in footnote $1: . \mathrm{R}_{\mathrm{t}}$ of $\mathbf{1 2} 15.4 \mathrm{~min}, \mathbf{1 3} 14.3 \mathrm{~min}$.
} 
401; mp $153{ }^{\circ} \mathrm{C}$; Anal. Calcd for $\mathrm{C}_{21} \mathrm{H}_{42} \mathrm{~N}_{2} \mathrm{O}_{9} \mathrm{~S}: \mathrm{C}, 50.58 ; \mathrm{H}, 8.49 ; \mathrm{N}, 5.62 ; \mathrm{S}, 6.43$. Found: C, 50.59; H, 8.55; N, 5.56; S, 6.47; HPLC AP (205 nm) 100.

Hexahydro-2,2-dimethyl-6-[[(1,1-dimethylethoxy)carbonyl)]amino]-7-oxo1H-azepine-1-acetic acid, 1,1-dimethylethyl ester (15a).

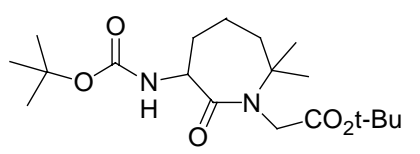

A mixture of 13c (126.7 g, $254.0 \mathrm{mmol})$, THF (1270 mL) and $\mathrm{H}_{2} \mathrm{O}(120 \mathrm{~mL})$ was cooled to $0{ }^{\circ} \mathrm{C}$. A solution of $\mathrm{LiOH} \cdot \mathrm{H}_{2} \mathrm{O}(22.4 \mathrm{~g}, 533.5 \mathrm{mmol})$ in $\mathrm{H}_{2} \mathrm{O}(280 \mathrm{~mL})$ was added slowly over $30 \mathrm{~min}$ such that the internal temperature of the stirring mixture never exceeded $2.5^{\circ} \mathrm{C}$. The container of $\mathrm{LiOH}$ solution was rinsed with $\mathrm{H}_{2} \mathrm{O}(20 \mathrm{~mL})$, and the rinse was added slowly to the reaction mixture. ${ }^{16}$ After $5 \mathrm{~h}$ the $\mathrm{pH}$ of the reaction was adjusted to 8.7 with $1 \mathrm{M} \mathrm{HCl}(100 \mathrm{~mL})$. THF was removed under vacuum, and the aqueous solution was washed with MTBE [ $2 \mathrm{x}$ $200 \mathrm{~mL}$ ); $3.47 \mathrm{~g}$ of the starting material 13c was recovered from these washings]. The $\mathrm{pH}$ of the aqueous layer was adjusted to 5 with $1 \mathrm{M} \mathrm{HCl}(180 \mathrm{~mL}) . \mathrm{CH}_{2} \mathrm{Cl}_{2}$ (860 $\mathrm{mL}$ ) was added, and the aqueous layer was saturated with solid $\mathrm{NaCl}$. The $\mathrm{pH}$ of the mixture was further adjusted to 3 with $1 \mathrm{M} \mathrm{HCl}(170 \mathrm{~mL})$, and the aqueous layer was further saturated with solid $\mathrm{NaCl}$. The aqueous layer was separated and extracted with $\mathrm{CH}_{2} \mathrm{Cl}_{2}(2 \times 200 \mathrm{~mL})$. The combined $\mathrm{CH}_{2} \mathrm{Cl}_{2}$ layers were dried $\left(\mathrm{MgSO}_{4}\right)$ and concentrated such that $1 \mathrm{~L} \mathrm{CH}_{2} \mathrm{Cl}_{2}$ remained. This solution of $\mathrm{HCl}$ salt $\mathbf{1 4}$ was charged into a 2-L flask equipped with a mechanical stirrer and an argon inlet. HOBT monohydrate (39.6 g, $292.7 \mathrm{mmol}$ ) was

\footnotetext{
${ }^{16}$ HPLC method: Column: YMC S3 ODS 4.6 x 50; Solvent A: $100 \% 0.2 \%$ aqueous $\mathrm{H}_{3} \mathrm{PO}_{4}$. Solvent B: $90 \% \mathrm{CH}_{3} \mathrm{CN}$ in water. Gradient: $10 \%$ to $100 \% \mathrm{~B}$ in $10 \mathrm{~min}$; flow rate $2.5 \mathrm{ml} / \mathrm{min}$; wave length $205 \mathrm{~nm}$. $\mathrm{R}_{\mathrm{t}}$ of 13a $4.3 \mathrm{~min}$. and $\mathbf{1 4} 3.5 \mathrm{~min}$.
} 
introduced and then DIPEA (49 mL, $262.9 \mathrm{mmol}$ ) was added dropwise over 10 min. EDC $(60.8 \mathrm{~g}, 317 \mathrm{mmol})$ was added and the mixture was stirred at room temperature for $2 \mathrm{~h} .{ }^{\top}$ The $\mathrm{CH}_{2} \mathrm{Cl}_{2}$ was removed in vacuum, and the residue was dissolved in EtOAc $(200 \mathrm{~mL})$ and concentrated. The material was taken up in a mixture of EtOAc $(1200 \mathrm{~mL}), 1 \mathrm{M} \mathrm{HCl}(800 \mathrm{~mL})$, and $\mathrm{H}_{2} \mathrm{O}(800 \mathrm{~mL})$. The organic layer was washed with saturated $\mathrm{NaHCO}_{3}(2 \times 600 \mathrm{~mL})$, brine $(1 \times 600 \mathrm{~mL})$ and then dried $\left(\mathrm{MgSO}_{4}\right)$. The solution was filtered and evaporated in vacuum and the product was dried under high vacuum overnight to provide 15a (69.06 g, 73\% overall yield from 13c, yield 76\% based on recovered 13c), HPLC AP (210 nm) 99.1. ${ }^{1} \mathrm{H}$ NMR $\left(270 \mathrm{MHz}, \mathrm{CDCl}_{3}\right) \delta, 1.38$ (s, 3H), 1.42 (s, 9H), 1.48 (s, 12H), 1.5 $-2.18(\mathrm{~m}, 6 \mathrm{H}), 3.85-4.30(\mathrm{AB} \mathrm{q}, 2 \mathrm{H}, \mathrm{J}=18 \mathrm{~Hz}), 4.55(\mathrm{~m}, 1 \mathrm{H}), 5.87(\mathrm{~d}, 1 \mathrm{H}, \mathrm{J}=8$ $\mathrm{Hz}) ;{ }^{13} \mathrm{C} \mathrm{NMR}\left(68 \mathrm{MHz}, \mathrm{CDCl}_{3}\right) \delta, 19.9,27.7,28.1,30.4,30.7,39.7,47.2,52.4$, 58.4, 78.8, 80.9, 154.7, 168.5, 172.1; IR (KBr) 3435, 3341, 1717, 1708, $1632 \mathrm{~cm}^{-}$ ${ }^{1}$; $\mathrm{MS}$ (ESI) $\mathrm{M}+\mathrm{H}=371, \mathrm{M}-\mathrm{H}=369 ; \mathrm{mp} 110^{\circ} \mathrm{C}$; Anal. Calcd for $\mathrm{C}_{19} \mathrm{H}_{34} \mathrm{~N}_{2} \mathrm{O}_{5}$ : C, 61.60; H, 9.25; N, 7.56. Found: C, 61.39, H, 9.42; N, 7.47.

6-Aminohexahydro-2,2-dimethyl-7-oxo-1H-azepine-1-acetic acid, 1,1dimethylethyl ester $(\mathbf{1 5 b})$.

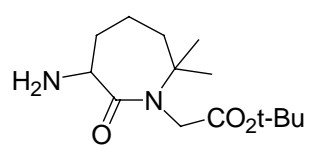

To a solution of ester $\mathbf{1 5 a}(14.81 \mathrm{~g}, 40.0 \mathrm{mmol})$ in $100 \mathrm{~mL} \mathrm{MeOH}$ was added dropwise MSA (5.58 mL, $58.08 \mathrm{mmol})$ and the mixture was stirred overnight. An aqueous solution of $\mathrm{NaHCO}_{3}$ was added to the mixture and $\mathrm{MeOH}$ was evaporated under vacuum. The mixture was acidified with aqueous $10 \% \mathrm{KHSO}_{4}$ to $\mathrm{pH} 1.5$ and washed with MTBE. The aqueous portion was saturated with $\mathrm{NaCl}$ and basified with aqueous $\mathrm{NaOH}$ to $\mathrm{pH}$ 10.7. The product was extracted three times

\footnotetext{
${ }^{17}$ HPLC method same as in footnote $1: \mathrm{R}_{\mathrm{t}}$ of $\mathbf{1 4} 12.4 \mathrm{~min}$ and $\mathbf{1 5 a} 24.4 \mathrm{~min}$.
} 
with $\mathrm{CH}_{2} \mathrm{Cl}_{2}$, dried $\left(\mathrm{MgSO}_{4}\right)$ and evaporated. The residue was dissolved in EtOAc and evaporated again and dried under vacuum to give $9.35 \mathrm{~g}$ (yield $84 \%$ ) of racemic ester 15b, HPLC AP $(210 \mathrm{~nm})$ 93.4. The ${ }^{1} \mathrm{NMR}$ of this compound was identical to that of the optically active compound $\mathbf{6 b}$.

(S)-6-Aminohexahydro-2,2-dimethyl-7-oxo-1H-azepine-1-acetic acid, 1,1dimethylethyl ester $(\boldsymbol{6} \boldsymbol{b})$. (via dynamic resolution)

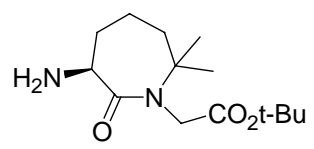

A 500-mL, three-necked, round-bottomed flask equipped with thermocouple, overhead stirrer, and nitrogen inlet was charged with (1R)-(-)-10camphorsulfonic acid (19.56 g, $84.3 \mathrm{mmol}, 0.9$ equiv) and 2-hydroxy-5nitrobenzaldehyde $(0.783 \mathrm{~g}, 4.7 \mathrm{mmol}, 0.05$ equiv). A solution of compound $\mathbf{1 5 b}$ $(25.33 \mathrm{~g}, 93.7 \mathrm{mmol})$ in toluene $(170 \mathrm{~mL})$ was added resulting in a temperature rise to $50^{\circ}$. The mixture was stirred at $60^{\circ}$ for $\sim 48 \mathrm{~h}$ while monitoring the e.e. of the slurry. ${ }^{12}$ The mixture was cooled slowly to room temperature and filtered. The product was washed with pre-chilled $\left(15-25^{\circ}\right)$ n-butyl acetate $(3 \times 75 \mathrm{~mL})$ and dried under vacuum to afford $37.5 \mathrm{~g}(80.7 \%)$ of the (R)-CSA salt of $\mathbf{6 b}$ with e.e. $>99 \% .^{12}$

Aqueous $\mathrm{NaOH}(1 \mathrm{~N}, 9.2 \mathrm{~mL}, 9.2 \mathrm{mmol})$ was added to a solution of this salt (4.38 g, $8.71 \mathrm{mmol})$ in $\mathrm{CH}_{2} \mathrm{Cl}_{2}(44 \mathrm{ml})$ containing $\mathrm{H}_{2} \mathrm{O}(26 \mathrm{~mL})$. The aqueous layer was separated and extracted with $\mathrm{CH}_{2} \mathrm{Cl}_{2}(3 \times 44 \mathrm{~mL})$. The organic layers were combined, dried $\left(\mathrm{MgSO}_{4}\right)$ and evaporated under vacuum. The residue was dried under vacuum to give $2.59 \mathrm{~g}$ (yield quantitative) of the amino ester $\mathbf{6 b}$, HPLC AP $(210 \mathrm{~nm})$ 99.1. The product made by this dynamic resolution method 
was identical to the compound $\mathbf{6 b}$ prepared by the method described in part I above.

\section{Part III. Conversion of (S)- $\alpha$-aminoazepinone $6 \mathrm{~b}$ to BMS-189921}

[S-( $\left.\left.R^{*}, R^{*}\right)\right]-6-[[2-($ Acetylthio)-1-oxo-3-phenylpropyl]amino]hexahydro-

2,2-dimethyl-7-oxo-1H-azepine-1-acetic acid, 1,1-dimethylethyl ester (17).

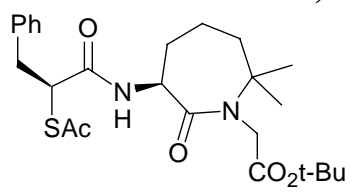

A solution of (S)- $\alpha$-aminoazepinone $6 \mathbf{b}\left(0.781 \mathrm{~g}, 2.8 \mathrm{mmol}\right.$, ) in $\mathrm{CH}_{2} \mathrm{Cl}_{2}(11 \mathrm{ml})$ was cooled in an ice-bath and powdered acid $16(0.641 \mathrm{~g}, 2.86 \mathrm{mmol})$ was added. A clear solution was obtained within several mipytes. EDC (0.642 g, $3.351 \mathrm{mmol})$ was added and the mixture was stirred for $2.5 \mathrm{~h} .{ }^{18}$ The solvent was evaporated and the residue was taken up in EtOAc $(25 \mathrm{~mL})$ and $1 \mathrm{~N} \mathrm{HCl}(15 \mathrm{~mL})$. The aqueous layer was separated and extracted with EtOAc $(25 \mathrm{~mL})$. The combined organic extracts were washed successively with $1 \mathrm{~N} \mathrm{HCl}(2 \times 15 \mathrm{~mL})$, brine $(15 \mathrm{~mL})$, saturated aqueous $\mathrm{NaHCO}_{3}(2 \times 10 \mathrm{~mL})$ and brine $(10 \mathrm{~mL})$. The solution was dried $\left(\mathrm{Na}_{2} \mathrm{SO}_{4}\right)$ and evaporated to give $1.32 \mathrm{~g}$ (yield $\left.93 \%\right)$ of $\mathbf{1 7}$ as a white foam. HPLC, AP (205 nm) 95.7; Diastereomeric purity (220 nm) 97.9\%. Chiral HPLC ee $=97.8 .{ }^{1} \mathrm{H}$ NMR $\left(270 \mathrm{MHz}, \mathrm{CDCl}_{3}\right) \delta, 1.3(\mathrm{~s}, 3 \mathrm{H}), 1.4(\mathrm{~s}, 3 \mathrm{H}), 1.5(\mathrm{~s}, 9 \mathrm{H})$, $1.4(\mathrm{~m}, 1 \mathrm{H}$, masked), $1.8-2.0(\mathrm{~m}, 4 \mathrm{H}), 2.1(\mathrm{~m}, 1 \mathrm{H}), 2.3(\mathrm{~s}, 3 \mathrm{H}), 2.9-3.4(\mathrm{~m}, 2$ $\mathrm{H}), 3.9-4.3(\mathrm{AB} \mathrm{q}, 2 \mathrm{H}, \mathrm{J}=17.6 \mathrm{~Hz}), 4.3(\mathrm{~m}, 1 \mathrm{H}), 4.6-4.7(\mathrm{~m}, 1 \mathrm{H}), 7.2-7.3$ $(\mathrm{m}, 5 \mathrm{H}), 7.4(\mathrm{~d}, 1 \mathrm{H}, \mathrm{J}=5.9 \mathrm{~Hz}) .{ }^{13} \mathrm{C} \mathrm{NMR}\left(68 \mathrm{MHz}, \mathrm{CDCl}_{3}\right) \delta, 20.1,28.2,28.4$, 30.1, 30.8, 31.0, 37.3, 40.4, 47.8, 48.7, 52.6, 59.2, 81.7, 127.1, 128.7, 129.6, 138.0, 169.3, 169.6, 172.6, 194.7. IR (KBr) 3500, 3385, 1744, 1692, $1630 \mathrm{~cm}^{-1}$. MS (ESI) $\mathrm{M}+\mathrm{H}=477$, Anal. Calcd for $\mathrm{C}_{25} \mathrm{H}_{36} \mathrm{~N}_{2} \mathrm{O}_{5} \mathrm{~S} \bullet 0.4 \mathrm{H}_{2} \mathrm{O}: \mathrm{C}, 62.06 ; \mathrm{H}, 7.67$; N, 5.79; S, 6.63; $\mathrm{H}_{2} \mathrm{O}, 1.43$; Found: C, 62.28; H, 7.63; N, 5.75; S, 6.44; $\mathrm{H}_{2} \mathrm{O}, 1.49$. $[\alpha]_{\mathrm{D}}=-48.9(\mathrm{c}=1.0, \mathrm{EtOAc})$.

\footnotetext{
${ }^{18}$ (a). HPLC method same as in footnote $1: \mathrm{R}_{\mathrm{t}}$ 27.2. (b). HPLC conditions for diastereomeric purity: Solvent A: $90 \% 0.2 \%$ aqueous $\mathrm{H}_{3} \mathrm{PO}_{4}$ and $10 \% \mathrm{MeOH}$. Solvent B: $90 \% \mathrm{MeOH}$ and $10 \% \mathrm{MeOH} .72 \% \mathrm{~B}$ isocratic; flow rate $1.5 \mathrm{ml} / \mathrm{min}$; wave length $220 \mathrm{~nm}$.
} 
[S-( $\left.\left.R^{*}, R^{*}\right)\right]-6-[[2-($ Acetylthio)-1-oxo-3-phenylpropyl] amino]hexahydro2,2-dimethyl-7-oxo-1H-azepine-1-acetic acid (18).

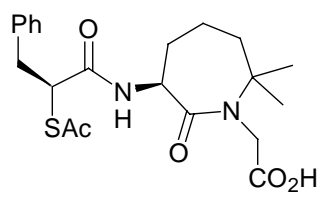

Trifluoroacetic acid $(9.0 \mathrm{~mL}, 126.0 \mathrm{mmol})$ was added to a solution of diester 17 (3.75 g, $7.88 \mathrm{mmol})$ in $\mathrm{CH}_{2} \mathrm{Cl}_{2}(30 \mathrm{~mL})$. After $5 \mathrm{~h}$ HPLC showed starting material 17 AP 0.3. ${ }^{19} \mathrm{Na}_{2} \mathrm{HPO}_{4} \bullet \mathrm{H}_{2} \mathrm{O}(8.4 \mathrm{~g}, 59.1 \mathrm{mmol})$ dissolved in $50 \mathrm{~mL} \mathrm{H}_{2} \mathrm{O}$ was added to the reaction mixture chilled in an ice-bath. The $\mathrm{pH}$ of the mixture dropped to 1.4 ( $\mathrm{pH}$ meter) and was adjusted to 2.9 with $10 \mathrm{~N} \mathrm{NaOH}$. The layers were separated and the organic layer was washed with a solution of $\mathrm{NaH}_{2} \mathrm{PO}_{4}(0.5$ $\mathrm{g}$ ) in $25 \mathrm{~mL}$ of $\mathrm{H}_{2} \mathrm{O}$ after adjusting its $\mathrm{pH}$ to 2.9 with conc. $\mathrm{HCl}$. The layers were separated and the aq. layers were backwashed with $\mathrm{CH}_{2} \mathrm{Cl}_{2}(5 \mathrm{~mL})$. The combined organic layers were dried $\left(\mathrm{Na}_{2} \mathrm{SO}_{4}\right)$, and evaporated. The residue was dissolved in $\mathrm{CH}_{2} \mathrm{Cl}_{2}(6 \mathrm{~mL})$ and heptane $(24 \mathrm{~mL})$ was added slowly with stirring over 20 min. The resulting mass of crystals was stirred overnight, filtered, washed with $\mathrm{CH}_{2} \mathrm{Cl}_{2}$ /heptane 1:9, and heptane, and dried under vacuum to give $3.08 \mathrm{~g}$ (93\%

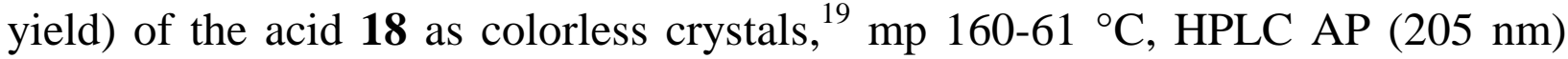
95.2; AP 17 0.5; HPLC for the diastereomeric purity: AP $(220 \mathrm{~nm}) 98.9 .{ }^{1} \mathrm{H}$ NMR $\left(270 \mathrm{MHz}, \mathrm{CDCl}_{3}\right) \delta, 1.35(\mathrm{~s}, 3 \mathrm{H}), 1.45(\mathrm{~s}, 3 \mathrm{H}), 1.4(\mathrm{~m}, 1 \mathrm{H}), 1.8-2.2(\mathrm{~m}, 5 \mathrm{H})$, $2.9-3.4(\mathrm{~m}, 2 \mathrm{H}), 3.9-4.4(\mathrm{AB} \mathrm{q}, 2 \mathrm{H}, \mathrm{J}=17.6 \mathrm{~Hz}), 4.2-4.3(\mathrm{~m}, 1 \mathrm{H}), 4.7-4.8$ $(\mathrm{m}, 1 \mathrm{H}), 7.2-7.3(\mathrm{~m}, 5 \mathrm{H}), 7.35(\mathrm{~d}, 1 \mathrm{H}, \mathrm{J}=5.9 \mathrm{~Hz}) .{ }^{13} \mathrm{C} \mathrm{NMR}(68 \mathrm{MHz}$, $\left.\mathrm{CDCl}_{3}\right) \delta, \quad 20.2,27.9,29.7,30.4,30.7,36.8,39.8,46.8,48.3,52.2,59.3,126.8$, 128.4, 129.3, 137.6, 169.3, 172.9, 174.9, 194.6. IR (KBr) 3315, 1755, 1702, 1622 $\mathrm{cm}^{-1}$. MS (ESI) $\mathrm{M}+\mathrm{H}=421$; Anal. calc for $\mathrm{C}_{21} \mathrm{H}_{28} \mathrm{~N}_{2} \mathrm{O}_{5} \mathrm{~S} \bullet 0.1 \mathrm{H}_{2} \mathrm{O}: \mathrm{C}, 59.72 ; \mathrm{H}$, 6.73; N, 6.63; S, 7.59, $\mathrm{H}_{2} \mathrm{O}, 0.43$; Found: $\mathrm{C}, 59.29, \mathrm{H}, 6.61 ; \mathrm{N}, 6.55 ; \mathrm{S}, 7.56, \mathrm{H}_{2} \mathrm{O}$, $0.1(\mathrm{KF}) .[\alpha]_{\mathrm{D}}=-46.6\left(\mathrm{c}=0.7, \mathrm{CHCl}_{3}\right)$.

19

Structure of the acid $\mathbf{1 8}$ was confirmed by single crystal x-ray analysis. Coordiantes from the X-ray determinations have been deposited in the Cambridge Crystallographic Database and can be obtained upon request to the Director, Cambridge Crystallographic Data Center, 12 Union Road, Cambridge, CB2 1EZ, UK. 
[S- $\left.\left(R^{*}, R^{*}\right)\right]$-Hexahydro-6-[(2-mercapto-1-oxo-3-phenylpropyl)amino]-2,2dimethyl-7-oxo-1H-azepine-1-acetic acid (BMS-189921).

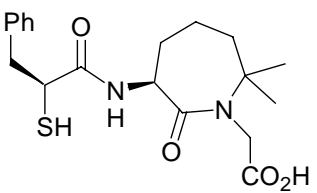

DL-dithiothreitol ( $0.049 \mathrm{~g}, 0.32 \mathrm{mmol})$ was added to a suspension of $\mathbf{1 8}$ (2.67 g, $6.35 \mathrm{mmol})$ in methanol $(8.5 \mathrm{~mL}){ }^{20}$ The suspension was sparged with argon for $15 \mathrm{~min}$, cooled to $1^{\circ} \mathrm{C}$, and kept under argon atmosphere. In an addition funnel $1 \mathrm{~N}$ $\mathrm{NaOH}(25.4 \mathrm{~mL}, 25.4 \mathrm{mmol})$ was sparged with argon for $20 \mathrm{~min}$ and then added to the reaction mixture over $20 \mathrm{~min}$ such that the internal temperature did not exceed $5^{\circ} \mathrm{C}$. After $30 \mathrm{~min}$ the ice bath was removed to allow the mixture to warm to room temperature over $1 \mathrm{~h}^{22} \mathrm{~A} \mathrm{pH}$ probe and a reflux condenser were attached to the reaction flask. The mixture was acidified with previously sparged $3 \mathrm{~N} \mathrm{HCl}$ solution to $\mathrm{pH}$ 6. The mixture was warmed to $40^{\circ} \mathrm{C}$ and seed crystals of BMS189921 were added, and the mixture was further acidified with stirring to $\mathrm{pH} 2$. At this point, the product crystallized. The resulting slurry was stirred at $40^{\circ} \mathrm{C}$ for $30 \mathrm{~min}$ and then allowed to cool to room temperature over $1 \mathrm{~h}$. The product was filtered and washed with distilled water $(\sim 35 \mathrm{~mL})$ until the water wash tested negative for chloride with $\mathrm{AgNO}_{3}$ solution. The product was air-dried for $30 \mathrm{~min}$ and then washed with MTBE $(2 \times 5 \mathrm{~mL})$ and hexane $(2 \times 5 \mathrm{~mL})$, air-dried, and finally dried under high vacuum overnight to give BMS-189921 (2.21 g, 92\% yield) as a white solid. ${ }^{21} \mathrm{H}$ NMR $\left(270 \mathrm{MHz}, \mathrm{CDCl}_{3}\right) \delta, 1.37(\mathrm{~s}, 3 \mathrm{H}), 1.4(\mathrm{~s}, 3 \mathrm{H})$,

20 (a). Robl, J. A.; Sulsky, R.; Sieber-McMaster, E.; Ryono, D. E.; Cimarusti, M. P.; Simpkins, L. M.; Karanewski, D. S.; Chao, S.; Asaad, M. M.; Seymour, A. A.; Fox, M.; Smith, P. L.; Trippodo, N. C. J. Med. Chem., 1999, 42, 305. (b). Kronenthal, D. R.; Deshpande, R. P. Patent US 644810, Sept. 3, 2002.

${ }^{21}$ HPLC method same as in foot note 16: $\mathrm{R}_{\mathrm{t}} \mathbf{1 8} 6.2 \mathrm{~min}$ and BMS-189921 $6.0 \mathrm{~min}$. Reference samples of enanatiomer ii and diastereomers iii and iv were prepared from the corresponding precursors by methods similar to the synthesis of BMS-189921. 
$1.5(\mathrm{~m}, 1 \mathrm{H}), 1.9-2.1(\mathrm{~m}, 6 \mathrm{H}), 3.0-3.3(\mathrm{~m}, 2 \mathrm{H}), 3.6-3.7)$; (m, $1 \mathrm{H}), 4.0-4.3$ $(\mathrm{AB} \mathrm{q}, \mathrm{J}=18 \mathrm{~Hz}, 2 \mathrm{H}$ ) $), 4.76-4.8(\mathrm{~m}, 1 \mathrm{H}), 7.2-7.3(\mathrm{~m}, 5 \mathrm{H}), 7.78(\mathrm{~d}, 1 \mathrm{H}, \mathrm{J}=$ $5.9 \mathrm{~Hz}) .{ }^{13} \mathrm{C}$ NMR $\left(68 \mathrm{MHz}, \mathrm{CDCl}_{3}\right) \delta, 20.3,28.1,29.8,30.8,39.9,41.4,44.8$, 46.9, 52.3, 59.5, 127.1, 128.6, 129.6, 137.7, 171.4, 173.2, 174.3. IR (KBr) 3500, $1748,1715,1620 \mathrm{~cm}^{-1} . \mathrm{mp} 174{ }^{\circ} \mathrm{C}$. MS (ESI) $\mathrm{M}+\mathrm{H}=379, \mathrm{M}-\mathrm{H}=377$. Anal. calc. for $\mathrm{C}_{19} \mathrm{H}_{26} \mathrm{~N}_{2} \mathrm{O}_{4} \mathrm{~S}: \mathrm{C}, 60.30 ; \mathrm{H}, 6.92 ; \mathrm{N}, 7.40 ; \mathrm{S}$, 8.47. Fd. C, 60.25; H, 6.96; $\mathrm{N}, 7.25 ; \mathrm{S}, 8.61 .[\alpha]_{\mathrm{D}}=-17.6\left(\mathrm{c}=1.0, \mathrm{CHCl}_{3}\right)$, Chiral HPLC AP, ee 99.0 .

Part IV. Reference samples of the byproducts disulfide 19 and azalactone (i) (footnote 17) were prepared by the following procedures:

[R-( $\left.\left.R^{*}, S^{*}\right)\right]$-Hexahydro-6-[(2-mercapto-1-oxo-3-phenylpropyl)-amino]-2,2dimethyl-7-oxolH-azepine-1-acetic acid (19).

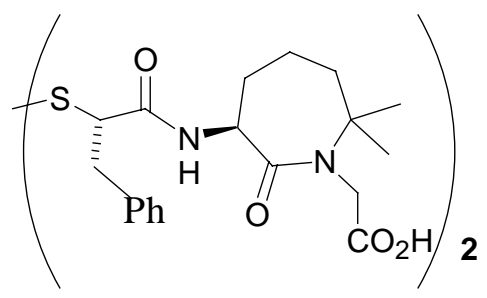

A solution of $\mathrm{NaHCO}_{3}(0.89 \mathrm{~g}, 10.57 \mathrm{mmol})$ in $\mathrm{H}_{2} \mathrm{O}(65 \mathrm{~mL})$ and $\mathrm{THF}(5 \mathrm{~mL})$ was stirred at $20{ }^{\circ} \mathrm{C}$. BMS-189921 (1.00g, $\left.2.64 \mathrm{mmol}\right)$ was added, and the mixture was stirred for $15 \mathrm{~min}$ for complete dissolution. $\mathrm{O}_{2}$ was bubbled through the solution for $30 \mathrm{~min}$, and the solution was stirred under an $\mathrm{O}_{2}$ atmosphere. When necessary, the $\mathrm{pH}$ was adjusted to 7.5 with $0.5 \mathrm{~N} \mathrm{HCl}$. Oxygen was bubbled through the solution for an additional $4 \mathrm{~h}$, and the solution was stirred under an $\mathrm{O}_{2}$ atmosphere for an additional $18 \mathrm{~h}$. The solution was acidified to $\mathrm{pH} 2.0$ with $6.0 \mathrm{~N}$ $\mathrm{HCl}$ and extracted with ethyl acetate $(2 \times 100 \mathrm{~mL})$. The combined extracts were washed once with sat. aq. $\mathrm{NaCl}(50 \mathrm{~mL})$, dried with $\mathrm{MgSO}_{4}$, filtered, and concentrated in vacuum to give a solid. The solid was evaporated twice from

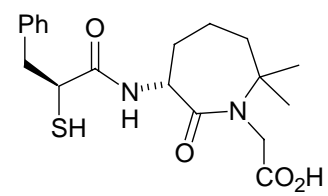

ii

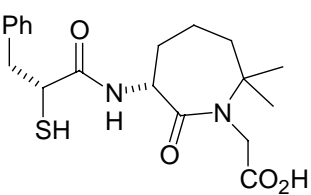

iii

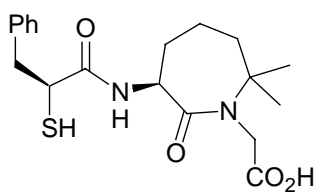

iv 
hexane and dried under high vacuum to give $1.00 \mathrm{~g}$ (100\% yield) of disulfide 19 as a white solid. m.p. $110{ }^{\circ} \mathrm{C},{ }^{1} \mathrm{H} \mathrm{NMR}\left(270 \mathrm{MHz}, \mathrm{CDCl}_{3}\right) \delta, 1.35(\mathrm{~s}, 6 \mathrm{H}), 1.4(\mathrm{~s}$, $6 \mathrm{H}), 1.7-2.1(\mathrm{~m}, 12 \mathrm{H}), 2.9-3.05(\mathrm{~m}, 2 \mathrm{H}), 3.1-3.25(\mathrm{~m}, 2 \mathrm{H}), 3.78(\mathrm{t}, \mathrm{J}=7.5 \mathrm{~Hz}$, $2 \mathrm{H}), 3.95-4.1(\mathrm{ABq}, \mathrm{J}=16.8 \mathrm{~Hz}, 4 \mathrm{H}), 4.7-4.9(\mathrm{~m}, 2 \mathrm{H}), 7.1-7.3(\mathrm{~m}, 10 \mathrm{H}), 7.6$ (d, J = 7.5 Hz), 9.6 (bs, 2H) ; IR (KBr) 3490, 1738, $1626 \mathrm{~cm}^{-1}$; MS (ESI): M - H = 1507.

\section{TFA salt of azalactone (i) (footnote 17):}

$\left[S-\left(R^{*}, R^{*}\right)\right]$-[[4-[1-(Acetylthio)-2-phenylethyl-4,5-dihydro-5-oxo-4-

oxazolyl]-1,1-dimethylbutyl]amino]acetic acid, trifluoroacetate (1:2).

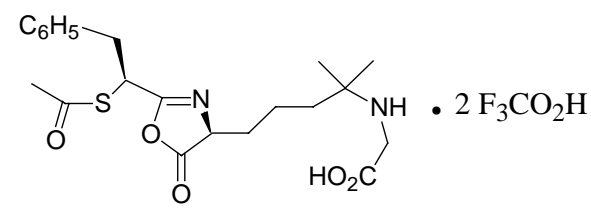

Compound 17 (3.23 g, $7.69 \mathrm{mmol})$ was dissolved in TFA $(7 \mathrm{~mL})$ and stirred at ambient temperature under an argon atmosphere. After $72 \mathrm{~h}$ the TFA was evaporated. The residue was dissolved in MTBE $(4 \mathrm{~mL})$, and hexane (30 $\mathrm{mL}$ ) was added until no more precipitate was formed. The supernatant layer was decanted, and the residue, a colored oil, was washed with hexane $(2 \mathrm{x}$ $10 \mathrm{~mL}$ ) and dried under vacuum to give $5.15 \mathrm{~g}$ (97.5\% yield) of the TFA salt of (i) as a rose-colored oil. ${ }^{1} \mathrm{H}$ NMR $\left(270 \mathrm{MHz}, \mathrm{CDCl}_{3}\right) \delta, 1.55(\mathrm{~s}, 6 \mathrm{H})$, 1.55 - $1.9(\mathrm{~m}, 6 \mathrm{H}), 2.35(\mathrm{~s}, 3 \mathrm{H}), 2.9-3.1(\mathrm{~m}, 2 \mathrm{H}), 3.2-3.35(\mathrm{~m}, 2 \mathrm{H}), 3.9-$ $4.13(\mathrm{~d}$ of $\mathrm{ABq}, 2 \mathrm{H}, \mathrm{J}=3.7$ and $16 \mathrm{~Hz}), 4.3-4.4(\mathrm{t}, 1 \mathrm{H}, \mathrm{J}=3.5 \mathrm{~Hz}), 4.55-$ $4.7(\mathrm{~m}, 1 \mathrm{H}), 7.04(\mathrm{~m}, 1 \mathrm{H}), 7.21-7.36(\mathrm{~m}, 5 \mathrm{H}), 11.0(\mathrm{bs}, 3 \mathrm{H}) ;{ }^{13} \mathrm{C} \mathrm{NMR}$ (68 MHz, $\left.\mathrm{CDCl}_{3}\right) \delta, 20.4,26.2,26.4,32.8,37.6,40.6,42.3,49.2,53.8,89.7$, $128.1,129.5,129.8,130.0,137.8,172.7,173.1,173.2,196.9$. MS (ESI) M + $\mathrm{H}=421, \mathrm{M}+\mathrm{TFA}+\mathrm{H}=535 ; \mathrm{M}-\mathrm{H}=419, \mathrm{M}+\mathrm{TFA}-\mathrm{H}=533 ;[\alpha]_{\mathrm{D}}=-$ $51.2(\mathrm{c}=1.86, \mathrm{THF})$. 